2019-09-12

Territory, geoeconomics and power politics: The Irish government's framing of Brexit

\title{
holden, patrick
}

http://hdl.handle.net/10026.1/14978

10.1016/j.polgeo.2019.102063

Political Geography

Elsevier

All content in PEARL is protected by copyright law. Author manuscripts are made available in accordance with publisher policies. Please cite only the published version using the details provided on the item record or document. In the absence of an open licence (e.g. Creative Commons), permissions for further reuse of content should be sought from the publisher or author. 
This is the author's accepted manuscript. The final published version of this work (the version of record) is published by Elsevier in Political Geography.

This work is made available in accordance with the publisher's policies. Please refer to any applicable terms of use of the publisher.

Acceptance date 20 August 2019 
Territory, geoeconomics and power politics: the Irish government's framing of Brexit

\section{Introduction}

Brexit confronted the European Union with an unprecedented challenge, as a leading member state declared its plan to leave the broader European legal and regulatory space. Brexit confronted Ireland in particular with a number of grave challenges and threatens to revive a long dormant power struggle between the Irish state and the United Kingdom. The issues raised by Brexit cut across economic and political issues, none more so than the Irish border where issues of political economy, identity and geopolitics intersect. This article concentrates on a particular political and geoeconomic intersection, specifically on the political implication of Ireland's efforts to preserve the all-Ireland socio-economic space. Temporally, it focuses on the period between the vote and the political agreement on stage 1 in December 2017. During this period the core UK policy of withdrawing not just from the EU but the single market and customs union was settled and negotiations took place on that basis. Although the agreement of December 2017 resolved nothing definitively it is an appropriate landmark within which to conduct a study of the Irish reaction to the prospect of disintegration. The 'backstop' agreed in December 2017 for Northern Ireland would dominate much of the subsequent Brexit debate.

The article investigates how the Irish government conceived of, and framed, the protection of the all-Ireland space in the context of the aforementioned threat. The fundamental question is how Ireland moved from a settled cautious approach towards Northern Ireland to a relatively radical proposal to separate Northern Ireland (to a greater or lesser degree) from the rest of the UK. How does it frame the border and what is acceptable/unacceptable? How did Ireland frame its role within the broader European space and as a part of the EU in particular? What were the different 'spatial imaginaries' (Siles-Brügge, 2018) underlying the different UK and Irish/European framing of the future economic relationship? How do the geoeconomics of Brexit affect politics and in particular state power and territorial disputes? There is already a rich literature on borderlands and bordering in Europe (Kaplan and Häkli, 2002 ; Stokłosa and Besier 2014; Bürkner, 2017). This article does not primarily aim to contribute to that, rather the major focus is on the broader international relationship. As such it will contribute to our general understanding of how small states relate to their larger neighbours in the context of multi-scalar power structures? The course of the article is as follows. After outlining the theoretical and methodological framework it analyses the context of UK-Irish relations and Northern Ireland question in particular. It then discusses the particular 
challenge of Brexit and moves on the core analysis of the Irish governments' language and policy towards Brexit. This is outlined as a narrative to illustrate the dynamic of the Brexit protest. Lastly, it offers a broader interpretation of Irish discourses and practice with reference to the overarching concepts of territory and geoeconomics.

\section{Theoretical and methodological framework}

The theme here is the link between political territory and overlapping political and socio-economic spaces. The power of the capitalist territorial state over economic forces and flows has never been absolute (Mann, 1986: 450-494). The role of the territorial state came under particular challenge in the era of globalisation. A globalist transnational conception of economics downplayed the power and agency of the state vis a vis transnational forces and global economic space (Ohmae, 1995). Yet the hyper-globalism of the 1990s was always contested (in theory and practice). More geoeconomic approaches underlined the relevance of geographically located configurations of spatial economic power (states and regional blocs) as opposed to the vision of a smooth global market place (Litvak, 1990; Vlhma, 2017). This was most evident in the realm of trade politics where 'global' and 'neoliberal' institutions like the WTO actually functioned by means of individual states and blocs of states bargaining for access to each other's markets and thus using their own protectionism as a form of leverage (Wilkinson, 2006).

In Europe an unprecedented level of regional integration provided a uniquely smooth transnational economic space. This occluded many of the barriers between the territorial states of Europe. European economic, most obviously the customs union/common commercial policy and the single market removed trade barriers between countries and harmonised regulation to a large extent. Other forms of integration such as the Common Fisheries Policy moderated the traditional international tensions over fishing rights. Freedom of movement and the Schengen free travel area also forged a smooth pan-regional socio-economic space. Apart from Ireland, It is argued that European Integration has moderated other actual or potential ethnic territorial conflicts (Diez, Albert and Stetter, 2008). Of course this transnational space depends on thick institutions and a strong legal system and if one state departs from this system many issues are raised. It is also relevant that this transnationalism mainly applies within the EU, it is very much a geographically bound institution with powerful external political and economic borders (Anderson, 2007; Popescu, 2008; Browning, 2018). 
Especially relevant to understanding how the European system operates is the concept of structural power defined as the 'power to shape and determine the structures ... within which other states their political institutions, their economic enterprises ... have to operate' (Strange, 1994: 24-25). This is applicable to how European integration has created a massive market and regulatory area which, in a manner analogous to gravity, creates a pull on the economies and enterprises of states within Europe and its neighbourhood. A more specific articulation of this can be found in the term 'market power' (Damro, 2012) which refers to how large states/blocs can exert influence based on the size of their market. In the case of the bilateral Ireland-UK relationship this power effect is evident due to the larger size of the UK, which has a population and GDP over ten times greater than Ireland's. Although Ireland's trade has been diversified and the relationship with the UK made more symmetric a far greater proportion of Irish trade is with the UK than vice versa. In particular Irish agricultural exports and domestic small to medium sized enterprises are highly dependent on the UK (CSO, 2016). Furthermore, a great proportion of other Irish exports to Europe travel through the UK. The UK still hosts a far larger proportion of Irish citizens than vice versa. However, the UK is itself embedded in the broader European power structure. Thus Ireland can be understood as situated within various multi-scalar power structures which are interrelated but distinct, including the 'British isles', the European union and the global economy. All of the above refers to material forms of power but there are other important dimensions of power include ideational and discursive power, the capacity to shape the thought and discourse of other actors (Barnett and Duvall, 2005). This article analyses how the two dimensions interact.

In its analysis of how Brexit initially unfolded, this article rests on a mid-range constructivist theoretical framework, which views ideas and 'reality' as mutually constitutive (Checkel, 1998; Finnemore, and Sikkink, 2001). Actors' ideas shapes their actions and those with whom they interact and thus shapes reality over time; however they are in turn formed by 'reality' including geographical, material, legal and institutional structures which have developed historically (Fairclough, 2010a 255-257). Intersubjective ideas emerge primarily through linguistic discourse and thus discourse and reality are to an extent mutually constitutive. In this case we are looking at a how a particular problem, the Irish border in the context of Brexit, has been 'framed' by different actors to shape the emerging reality. Some assumptions are made as to the legal and geoeconomic context of Brexit (the underlying reality in this case). The focus here is on the Irish government but this is also considered in relation to the framing of the UK, the EU more broadly and Northern Irish actors. To frame is to represent a given issues in such a way as to promote a particular problem definition, causal interpretation, moral evaluation, and/or treatment recommendation' (Entman, 1993: 52). 
Framing analysis includes the style of language, the emotional connotations and the metaphors and (the 'cliff-edge') analogies used (Lakoff, 2001). Framing also involve the 'rhetorical enactment' of broader discourses (Thomas and Turnbull, 2017; Holden 2019), defined as coherent patterns of language embedded with ideological assumptions (Fairclough 2010). In this case we can isolate discourses of nationalism, international law (the rights of the Irish state and Irish nationals in Northern Ireland), liberalism (support for transnationalism, the liberty of economic and social flows), realism (the power of the European Union), geoeconomic discourse (emphasising the spatial and geographical power dimension of economic interaction), neoliberal globalist discourse (with a generic aterritorial conception of economic interaction) and discourses of European integration.

The study focuses on the speeches, interviews and formal policy papers of Irish leaders -74 in total (29 from the Kenny government and 45 from the Varadkar government) -from the Brexit vote up until the agreement on stage 1 in December 2017. At a basic linguistic level the study first analyses the form of language used. This includes the strength of language, the use of imperatives (must/need) and moral conditionals, as well as the directness and specificity of language (who is responsible, who should do what, by when?). This comprises a quantitative content analysis (frequency of key words/phrases, word clusters) conducted via NVivo software. The content analysis is divided in three. It monitors the use or non-use of territorial language and political geographical terms (see figure 2). It also monitors the use of other political terminology such as 'special status'. Lastly, it classifies the different types of emotions prevalent in Irish language on this issue. This CA mostly serves as a basis (delineating themes and language patterns) for a more qualitative analysis of the discourses used but is sometimes meaningful in itself. At the next stage the focus is on the overall framing of the problem and discourses employed by Irish leaders. In particular how does the government articulate its policy of preserving the all-island socio-economic space and the invisible border? What is the role of the Irish government in relation to broader European structures? How are agency and responsibility constructed, who has to do what? Key individual texts are analysed in their entirety, in line with Fairclough's methology, for a more complete picture of how Irish leaders were framing Brexit at specific points in time (Fairlough, 2010b). I analyse how they employ and interweave different discourses to construct space, identity, power and authority. (The discourses are delineated through standard vocabulary and argumentation associated with their use, as outlined above). The Government's framing is understood in relation to the broader power dynamics of the negotiations.

\section{The context: the unfolding of the 'Anglo-Irish' relationship}


It is a truism that the UK-Irish relationship is characterised by complex intense and overlapping political, social, cultural and economic relations. Geopolitical tensions between the idea of an independent Ireland (allied to European powers) and British power and sovereignty run deep. Historically, Ireland was of existential security importance for England and later the UK. Geopolitical concerns that Ireland would be a backdoor to Britain for European rivals were a major motivation for the consolidation of British power and control over the island in the 16th and 17th centuries (O'Dowd, 2007: 30). There is a long history of Irish nationalist/proto-nationalist forces allying with continental European powers from Spain to revolutionary France to the Kaiser's Germany. There were also fundamental geoeconomic tensions. The ability to pursue a separate economic and trade policy was a major motivation of moderate nationalists and republicans to repeal the union of 1801 . Economic considerations were vital in mobilising Northern Unionism to resist participation in all Ireland structures (devolved or fully independent) with a particular fear of the imposition of tariffs on trade with Britain. As the UK became a global power the situation of Ireland remained a constant problem. Churchill's famous quote echoes the reluctance of more recent 'global Britain' enthusiasts to engage with the intractable problems of their smaller neighbouring island. 'The whole map of Europe has been changed ... but as the deluge subsides and the waters fall short we see the dreary steeples of Fermanagh and Tyrone emerging once again'. (Churchill 1922).

The Irish state seceded from the UK (but not the British Empire) in 1923. It would achieve full effective independence by 1938 and became a republic in 1948. The Irish state did not, of course, include the entire territory of the island as six counties of Ulster (where a large Unionist majority wished to retain the link with Britain) formed Northern Ireland within the UK. Political relations between the new Irish state and the UK were extremely problematic. Initial disputes sprung from Irish governments' efforts to achieve full independence and also included a trade war in the 1930s. Irish neutrality in WWII led to much resentment and economic pressure. Irish refusal to accept the legitimacy of Northern Ireland was the other main ongoing sore point (this refusal was codified in the constitution of 1937). A linguistic struggle also took place with Ireland rejecting British nomenclature such as 'Éire', 'Southern Ireland' or even the Irish Republic but insisting on the name of Ireland (with all its connotations) for the state (Coakley, J. and O'Dowd, L. 2007: 879-880). Ireland was eventually ceded as the title of the state by the UK government.

After the outbreak of the 'troubles' in 1969, relations were particularly tempestuous and full of mutual recriminations. The UK tried to achieve greater security cooperation from Ireland which 
sought to change the status quo in terms of the constitutional status and internal politics of Northern Ireland. (The border proved to be un-manageable without, or even with, good cooperation from the Irish authorities). The two states were deeply intertwined and in a highly asymmetric way. Ireland's trade was wholly dependent on the UK (Fitzgerald, 2004) and its currency was linked to sterling until the 1970s. A Common Travel Area was maintained (not without some adjustments in World War II and for security measures) throughout this period. Irish migration to the UK was a vital social safety valve. All of this led to classic case of structural power with the Irish state having to follow the British lead (whether explicitly directed to or not). Most notably Ireland's accession to the European Communities in 1973 was inextricably linked with the UK (Hourihane, 2004: 5).

Gradually, via intense diplomacy concerning Northern Ireland (and relations within the EU) the political relationship was transformed. The Anglo-Irish Agreement of 1985 created an explicit regime of consultation for the Irish state in the affairs of Northern Ireland in return for recognition of the principles of consent and greater security cooperation. It is fair to say that relations at this stage were still characterised by an adversarial frame of mind. More profound changes occurred via the Downing Street Declaration (non-legally binding) between the two governments (1994) and the Good Friday Agreement/GFA in 1998. The GFA preamble notes that the state parties are 'partners in the European Union'. The EU had a role in the peace process as an actor (offering aid/economic inducements) but it was its structural effect that counted most. The EU provided a regular forum of intensive dialogue and consultation. It gave the Irish state a position of relative equality with the UK and increased its relative leverage. It is striking how much of the difficult diplomacy of the 1980s and early 1990s took place on the margins of European Council summits (Fitzgerald, 1991: 506). The EU also provided a means for the Irish state to transform its economic relations, building a much broader portfolio of trading and investment partners. Less prominently their joint role in European integration reduced the potential for geo-economic tension between the two states. Although the two states disagreed over the Common Agricultural Policy they developed firm alliances on other economic perspectives. The general transformative effects of European integration on Ireland are well known (Fitzgerald, 2004; Coakley, Laffan and Todd, 2005). Modernisation and increased economic prosperity and confidence within Ireland helped change the relationship with the UK. Irish trade changed from being overwhelmingly dependent on the UK, which took 55\% of all trade in 1973 (CSO, 2003: VII), to a broader trading pattern in which the UK accounted for less than $15 \%$ of international trade by 2016 (CSO, 2016: 30). More fundamentally, European integration forced a redefinition of sovereignty. The Single European programme in particular and then the establishment of EU citizenship in the Maastricht Treaty significantly removed many of the social 
and economic borders in Europe. To quote John Hume (arguably the primary architect of the new nationalist approach to partition) 'the border will be no more in real terms than a county boundary as goods, people and services move freely across it' (1994: 227). More abstractly he argued that the new integrated Europe did away with the 'winner takes all' zero-sum perception of relations between states (Ibid: 231). This allowed the Irish to think more flexibly about territory, partition and the different constituencies on the Island, moving the way to more flexible solutions, 'uniting people rather than territory', generally downplaying territorial sovereignty and developing a more liberal nationalism. Over the course of this process the discourse of British governments changed significantly, going so far as to declare that Britain had 'no selfish strategic or economic interest' in Northern Ireland (Downing Street Declaration, 1993). Successive British governments have respected the role of the Irish Government as co-guarantor of the GFA (and the St Andrew's agreement).

This new thinking lead to the Downing Street Declaration and the Good Friday Agreement. The traditional nationalist position (held by the largest parties to a greater or lesser degree) had been that Northern Ireland was a gerrymander engineered by British power, an approach which implicitly rejected Northern Ireland's legitimacy or at least its normalcy as a part of the UK. In the Good Friday Agreement, the Irish government relinquished its all-Island sovereignty claims and altered its constitution as a quid pro quo for reform within $\mathrm{NI}$, the establishment of all-Ireland institutions and changes to the constitutional position of NI within the UK (Good Friday Agreement, 1998). This is linked to how the change to 'national' all-Ireland self-determination was rationalised. The agreement states that 'it is for the people of this Island alone' to exercise self-determination thus privileging the Irish framework (O'Duffy, 2000: 413) and giving Northern Ireland a unique status within the UK. (Although the precise meaning and implications of this are open to debate). Sovereignty rested in Ireland but this self-determination was to be exercised in two distinct territories, thus recognising Northern Ireland and fully recognising the principle of consent. A (preexisting) duality was crystallised in Northern Ireland in terms of the right to be either British and /or Irish citizens. As a part of this the Uk repealed the Government of Ireland Act and agreed provisions for future unity of the Island, taking the unusual step of abstracting itself from the fate of one of its own provinces/nations.

As noted above the agreement also formalised a new (in this era) all-Ireland space as well as formalising British and Irish relations more generally (via the East-West dimension, the delicately named 'Council of the Isles'). From an Irish nationalist point of view the North-South dimension was 
crucial. This included a North-South Ministerial Council/NMSC to manage cooperation as well as six implementation bodies: InterTrade Ireland, the North South Language Body, the Foyle, Carlingford and Irish Lights Commission, The Food Safety Promotion Board, Waterways Ireland and the Special European Union Programmes Body. These were modest in scope (and operated under the guidance of the NSMC rather than being fully autonomous) but were symbolically important. This dynamic of island of Ireland economic integration continued with very substantial functional cooperation in areas such as the all-Ireland Single Electricity Market (DXEU, 2017: 22-23) and health care; although the private sector on the island remained relatively un-integrated (Roper, 2007). In summary the traditional antagonistic and asymmetric power relations were transcended via a complex series of institutions and norms combined with economic and social liberalisation.

Constructive ambiguity infuses much of the agreement in terms of where it is leading and indeed the real import of Britain's abstraction from the sovereignty of Northern Ireland. To what extent was the UK government expected to be neutral about the fate of a part of its territory? Over the next two decades the agreement and the intergovernmental partnership were consolidated: the many disputes about the interpretation of the GFA and the St Andrew's Agreement did not focus on the role of the governments. The Good Friday settlement was framed by the Irish government as a seachange in sovereignty. The then Taoiseach (Prime Minister) put this in extreme terms when he said that any 'British territorial claim of sovereignty' was being superseded (Ahern, 1998). On the other hand Unionists could argue, more plausibly, that the agreement secured Northern Ireland's status under British sovereignty. This element of constructive ambiguity and the very tangible all-island economy were contingent on joint membership of the European Union.

\section{The challenge of Brexit}

The meaning of Brexit as a geopolitical event is that it brings latent power politics, which had been submerged under liberal EU hegemony (Holden, 2017), up to the surface. Brexit, and in particular the approach of May's government, was a rejection of the pre-existing legal and institutional framework in Europe in which economic social and political issues are fused The desire to break away from the EU's customs union is a direct challenge to the assumption that only the EU can effectively represent European interests in the global economy. Of necessity it means an element of geo-economic rivalry between the UK and its former EU partners (who are complying with the rules it has rejected). It forces the EU to think of the UK as a potential rival especially in terms of international trade politics. This is a new development within the contemporary European space, 
which has included candidate countries and smaller 'associate members' of the single market. (Of course competition occurs within the EU, but it is moderated by features such as the following of common rules, the free movement of people, the need for constant negotiations within the 'family' and the sense of a common fate).

The UK's decision to leave the single market and the customs union created a range of problems for the Irish government and the island of Ireland. These have been extensively studied and reported on (House of Lords, 2017; House of Commons, 2017) and the core issues are only summarised here. The Common Travel Area between the UK and Ireland is called into question but this proved to be more solvable. However, the trade and economic context is more intractable. If there is no trade agreement or transitional agreement there would have to be a full customs border between Ireland and the UK (including tariffs and other checks). Even if there is a free trade agreement if the UK is outside the customs union there must be some form of customs checks (Hayward, Campbell and Murphy, 2017; Hayward, 2018), although of course the UK asked for the most frictionless trade possible. Likewise if it is outside the Single Market regulatory sphere there will have to be checks (even countries with a form of CU with the EU like Turkey have customs checks). All of the above requires a physical border in Ireland (ceteris paribus) and also presents major challenges to the Irish economy. The Irish border was never appropriate as a socio-economic barrier: it divides farms, cuts off Derry/Londonderry from its natural hinterland and there are over 270 crossings - most of which were closed during the troubles - along its winding $499 \mathrm{~km}$ path (see figure 1). Other aspects of island of Ireland integration (the electricity market for example) are put in question. A joint study of the EU and UK noted over 150 areas of North-South cooperation dependent on EU law (Department for Exiting the European Union, 2018). Brexit also arouses other territorial issues, including fisheries, that had been downplayed in recent decades. The most salient issue for the government was the prospect of a new 'physical border' which it argued posed grave political, security and socioeconomic risks (Government of Ireland, 2017).

The assumption of this article (in line with the general consensus) is that the UK has placed itself in a weak position vis a vis the EU. This is primarily due to the structural power of the EU and the fact that the UK is the protagonist which is trying to forge a new arrangement. The legal process of article 50 actualises this structural power in the sense that the departing country has to leave in 2 years and an abrupt departure would be far more damaging to the UK than to the EU as a whole. Thus Ireland, as a part of the EU, is a part of the more powerful entity. However, in another sense Ireland is uniquely vulnerable. As noted Ireland still has a large proportion of its trade with the UK, far larger 
than any other EU state. and is also reliant on the UK as a conduit for many exports to the rest of the EU. As such Ireland can be considered both a part of a powerful institution with the upper hand over the UK and also a card in the UK's deck as a tough economic deal for it would impact on Ireland.

Figure 1 The Irish border, including major transport links

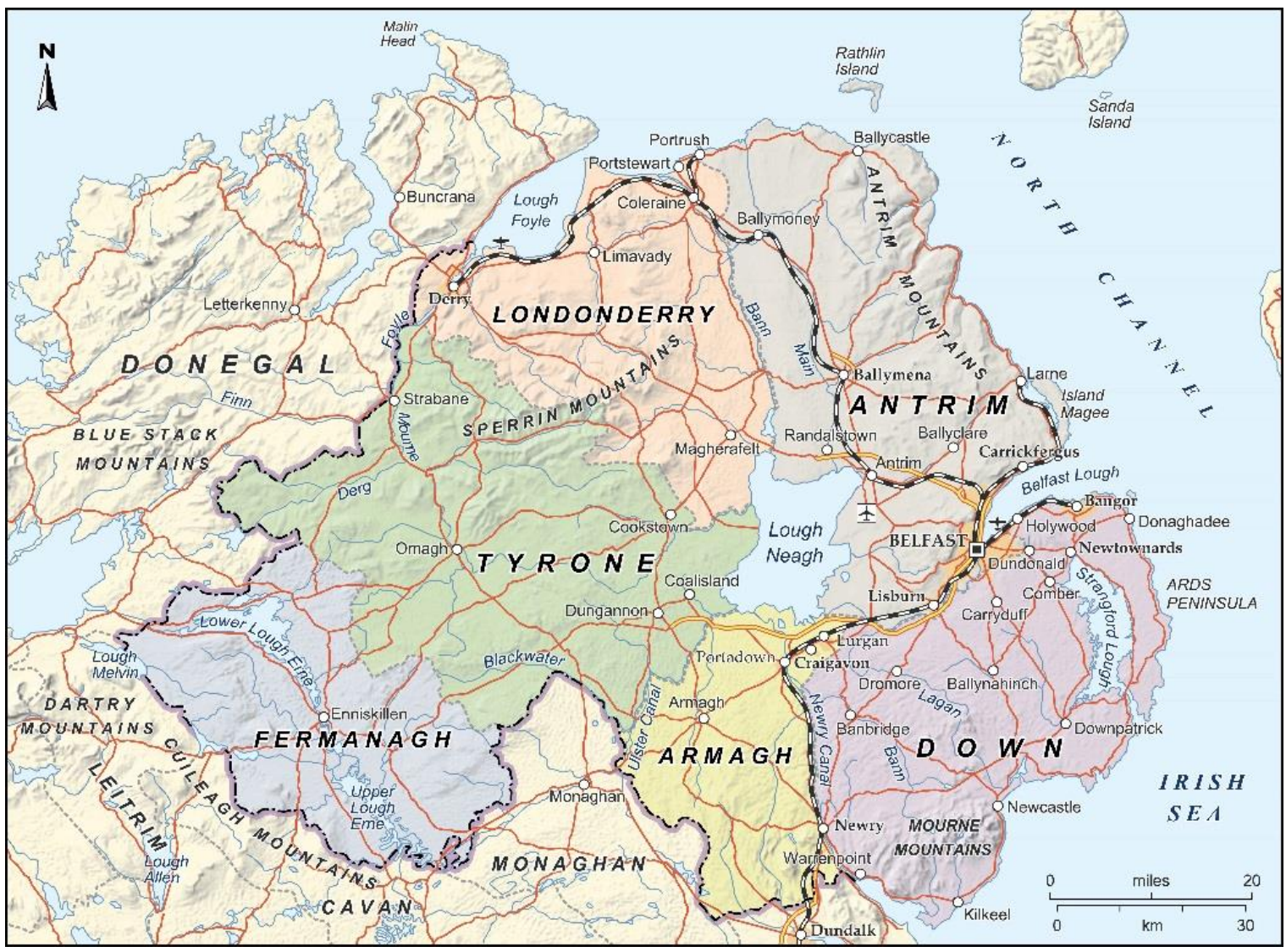

\section{Overview of how the Irish government reacted to Brexit. Period 1: The Irish Government's reaction to the Brexit vote and to the triggering of article 50}

When the Brexit vote occurred Fine Gael had been in power since 2011, with Enda Kenny as Prime Minister/ Taoiseach throughout this time. This was via a coalition with Labour until early 2016 and then on as a minority government working via a confidence and supply arrangement with Fianna Fáil (the other traditional centre-right Irish political party). Fine Gael is a strongly pro-European party (a longstanding member of the European Peoples' Party) and has always been regarded as less nationalist than Fianna Fáil (a party with more populist leanings that had traditionally taken a harder line on issues such as partition). The Irish Government had openly campaigned for a remain vote in 
the referendum and had engaged in contingency planning for a leave result, unlike the British government (Connelly, 2017).

The reaction to the Brexit vote took the form of an immediate press release and similarly worded statements in the Dáil (Kenny 2016a; Kenny 2016b). The Government reaffirmed Ireland's membership of and faith in the EU, also noting the 'unique bilateral interests' it had. It affirmed the importance of the GFA and the spirit of 'partnership and engagement' with which the UK's departure should be worked out. Notably Enda Kenny asserted that the European Council would have leadership of the process (this being the channel for member state influence). It is also noteworthy that he suggested that the talks on a future trade relationship would take place 'in parallel' (Kenny 2016b) with the talks on the terms of departure. A position that was quickly withdrawn to comply with the EU response. This response was robust and unified from the beginning: it stipulated that no negotiations could take place until Article 50 was triggered and that there would be no bilateral negotiations at all, the EU as a bloc would negotiate via the Commission (Consilium, 2016). Ways to persuade the UK as a state to remain were not considered. The major early decision that Ireland had to make was to support and comply with this unyielding EU approach, in particular the demand for no early bilateral negotiations (Whelan, 2017). Given the unique AngloIrish situation bilateral negotiations would have seemed natural but Ireland took the European option. (In fact Ireland had little real choice as anything other than full support for the EU could have put its own position in the EU in question). Ireland emphasised from the start that although it was geographically peripheral it wanted to remain at 'the heart of Europe' .

Generally the Irish government continued its cautious language but there were signals that things had changed. Enda Kenny. began to talk openly about the prospects for a united Ireland (Kenny, 2016c). This was not to demand a border poll but merely to clarify that a unified Ireland would inherit the Republic's membership (as per the German case). The Taoiseach also set in motion an AllIreland forum on Brexit against the wishes of the Northern Ireland unionists who did not participate. The Government emphasised the need to 'protect' the Good Friday Agreement and the need to avoid a 'hard border' (a mantra developed that there would be 'no return to the hard borders of the past'). The Democratic Unionist Party had supported Brexit but also agreed to support the continuation of free movement of goods and people across the island of Ireland.

The Government's policy of speaking softly while asserting its rights and role (combined with increased engagement with European partners) remained unchanged as the UK's position on Brexit 
developed in a manner unfavourable to Ireland. Prime Minister May's relatively hard-line position was confirmed in the Lancaster House speech of 17 January 2017 which clarified that the UK would not seek to stay in a customs union with the EU. A significant border between Ireland and the UK was now the default option. Over this time Ireland had launched an unprecedented diplomatic campaign in Brussels and member states, focused overwhelmingly on the question of the all-island socio-economic space (Connelly, 2017). This included hosting EU leaders and politicians and visiting the actual border, so as better to understand the physical reality.). The government's official reaction to the Lancaster House speech was modest but Kenny's speech the following month articulated a tougher stance (see box 1). This speech illustrates that the contrast made in the media between Kenny's 'gentle' approach and his successor's tougher approach was invalid. The government was clearly gearing up for a tough realpolitik negotiation at this time.

Box 1 The Taoiseach's speech to the Institute of International and European Affairs 14 February 2017

This speech begins evoking tumult and crisis. The Taoiseach draws on a sense of nationalism/patriotism noting the many great struggles the Irish people have faced in the past (including the Easter Rising of 1916) while disowning any kind of 'narrow nationalism' Kenny anchors Ireland in Europe underlining the common values of Europe, drawing on liberal discourse (stressing the need to be open) and describing Ireland as a 'European island nation' at the 'heart of Europe'. He stresses the economic and social benefits of European Integration for Ireland.

Drawing on nationalist discourse to an extent, he expresses a sense of responsibilities towards ' the North' which is being 'removed from the European Union' despite a strong remain majority.

'Of course I will do my best to put forward the interests of the North'. He also notes the 'vital national interest for Ireland that we do not return to the days of a hard border'. In stressing 'This is a political matter, not a legal or technical matter' he emphasises the importance of this issue. The anti-border frame is embedded in liberal discourse as he discusses/critiques other historical borders (the Iron Curtain and the Berlin wall).

Kenny places Ireland firmly within the European power structure in contrast to what the Taoiseach refers to as 'our British friends' (a gentle form of 'othering'):

'Our negotiations with the UK must recognise the wider, long-term interests of Europe and all of her people'.

'Ireland will be on the EU side of the table when the negotiations begin.

'We will seek an outcome that is good for Europe and good for Ireland. We will negotiate from a position of unity and strength'.

The rest of the speech covers the need for economic diversification, increased competitiveness and growth. Overall, the speech articulates a sense of historic crisis, tension and threat, stressing the need for unity and (potentially) sacrifice.

Source: Kenny, 2017. 
GOI's tangible input into the process came in helping to shape the EU's negotiation mandate for the European Commission once Article 50 had been triggered. This text asserts the EU-27's control over the process in no uncertain terms. Substantially it outlines that three core issues (citizens' rights, the financial settlement and the Irish border) must be agreed before there can be any talk of a future relationship. The language on Ireland very much reflected the GOI's language:

'in view of the unique circumstances on the island of Ireland, flexible and imaginative solutions will be required, including with the aim of avoiding a hard border, while respecting the integrity of the Union legal order'. (Author's emphasis).

A later European Council statement clarified that Northern Ireland could re-join the EU by unifying with the Republic, an important but essentially defensive move by the Irish government. In May 2017 the Irish government released an official position paper, which reiterated the core stance in more detail (Government of Ireland, 2017).

All in all the Irish government had asserted its rights but in the year since the vote Brexit had progressed in a manner unfavourable to it. Its language can be contrasted with that of Fianna Fáil and Sinn Féin (the main opposition parties). The leadership of Fianna Fáil (unsurprisingly for an opposition party) was much more direct in its criticism of the Brexit campaign's 'irresponsible populism' and the 'bombastic complacency' of May's government (Martin, 2016; Martin, 2017). Sinn Féin the all-Ireland nationalist party was stronger still. It labelled Brexit a 'hostile act' (Sinn Féin, 2017), an undermining of the Good Friday Agreement and used words such as 'disaster' in relation to it. Sinn Féin's major policy proposal was to call for 'special status' for Northern Ireland and for a border poll on reunification. The then Minister for Foreign Affairs rejected this, arguing that the phrase 'special status' was not welcomed by European partners (Flanagan, 2016a). Within Northern Ireland itself the situation darkened as the power-sharing executive collapsed in January 2017 and was not revived, leaving NI without a government. The DUP's new role in backing the government make compromise more difficult. The DUP itself declared that it did not want a new border but adopted policy positions at this time (leaving the single market and customs union) which made this inevitable. Brexit as an event posed real threats to the delicate political equilibrium that had existed in Northern Ireland (Murphy, 2018). It also posed a significant threat to the Northern Irish economy, already one of the weakest regions in the UK and Ireland (ibid: 67-96). The lack of an executive, and the remain vote in the province, made the situation more complicated. Both the Irish government and the DUP could claim be speaking for 'Northern Ireland', (in supporting the evident wish of its people to maintain links with the EU and as the largest political party respectively). 


\section{Period 2: The new Fine Gael leadership}

On June $14^{\text {th }} 2017$ Enda Kenny was replaced by Leo Varadkar as Taoiseach while foreign minister Charles Flanagan was replaced by Varadkar's leadership rival Simon Coveney. The new leadership was considerably younger than their predecessors and they shared a very strong commitment to the European Union and internationalism. This transition coincided with a new (weaker) UK government (dependent on a confidence and supply agreement with the DUP) and the formal opening of Article 50 negotiations. On the first day the UK's lead negotiator David Davis had to accept the EU's sequence for the negotiations. The substantive discussions on the three foregrounded issues began soon after. The subsequent period saw a sharpening of the rhetoric between the governments. The UK's decision to revoke the London Convention on fisheries was made without forewarning. The Irish Fisheries Minister declared that it would be 'a matter for the Brexit negotiations', hinting that the power of the EU would be brought to bear (Dunning, 2017). The outgoing Irish ambassador to London gave a speech on 18 July which also more direct in terms of its criticisms of Brexit arguments and his 'sadness', 'regret' and 'worry' at the situation (Mulhall, 2017). In the last week of July a minor media storm took off, beginning with a story in the Times that the Irish government was taking a harder line and hoping to push border checks back to an inter-Island basis. What became known as the 'sea-border' was something had not yet publicly demanded. The Foreign Minister was clear that the proposed 'technical solutions' to the border problem he'd seen wouldn't work and that a 'unique political solution' was needed. In response to Unionist anger about the proposed seaborder he noted ' we cannot support any British proposals or EU proposals for that matter, that result in the re-emergence of a border on the island on Ireland' (Coveney, 2017a).

A new tone came from the Taoiseach who declared that 'he wouldn't design a border for the Brexiteers',. He also added later 'if anyone should be angry it's us' (Minihan, 2017). This was noteworthy in its singling out of the 'Brexiteers' and it is challenging them more directly and framing the situation as a problem they had to solve. These words were given wide coverage in the British media. This viewpoint was outlined more substantially in a speech in Belfast the following week (see Box 3 ) in which his power was asserted more directly. Ireland had an effective veto over the move to the next phase of the negotiations. The government's new tone was criticised by Northern Ireland Unionists as 'megaphone diplomacy' (Donaldson, 2017). As the Irish government pointed out the risks to the UK of downgrading economic relations with its neighbours the Unionists emphasised the danger to Ireland of an economic divorce with its larger neighbour (Lord Kilclooney, 2017). 
In August 2017 the UK released a series of position papers on the Brexit talks and the future partnership with the EU. The two of most relevance here are those on the customs union and on Ireland/Northern Ireland itself (DXEU, 2017b). Regarding the customs union the UK proposed an immediate transition period in which the UK would maintain the customs union but have the right to negotiate new trade deals. After that the UK proposed more complex and creative ways of aligning UK customs procedures with that of the EU to minimise disruption to trade (DXEU, 2017A). The paper goes so far as to state that there should be no physical border infrastructure. The UK's ideas to avoid a hard border rested on the idea of a special customs partnership (unacceptable to the EU) or the use of state of the art technology (not viewed as feasible). The Irish government welcomed the aspirations but questioned the detail. The foreign minister asserted that Ireland 'will not be a pawn in the negotiations' and gave a vigorous interview in which he reiterated the geoeconomic power issues at hand :

'If Britain decides to take an approach that applies different food safety standards to Britain and $\mathrm{NI}$ from the common market well then we have a real problem. There are two sides to this negotiation. The other happens to represent 27 countries... The idea that Britain is going to be able to negotiate its own free trade agreements with countries all over the world and at the same time expect barrier-free access into the single market I don't think that that in itself is realistic' (Coveney, 2017b).

Days later the Taoiseach again directly criticised the UK's cherry-picking approach and explicitly explained that he had a veto over the talks moving on (McAdam, 2017).

Varadkar clarified Ireland's policy in his Belfast speech suggesting the customs union option for the UK as a whole (asking the UK to look again). Short of this occurring, the implication seems to be some kind of 'special status' (without using the words) for Ireland. Coveney reaffirmed this in arguing for 'Northern Ireland to become an extension of the EU customs union, to create equivalence north and south of the border' (Coveney, 2017b). This position solidified in the negotiations in the final three months before the agreement. At this time the negotiations approached the dimensions of a traditional Anglo-Irish dispute. The Commission supported the Irish position. The UK government (now dependent on any DUP support) reacted strongly against any implication of differentiating Northern Ireland from the rest of the UK, viewing it as a threat to its 'constitutional integrity'. Nationalist political parties in Northern Ireland (and Ireland) strongly supported the Irish position and the Unionist parties of Northern Ireland strongly supported the UK 
government position. All in all the Irish government's position on Northern Ireland had changed substantially. This was in reaction to a political process that it was not responsible for. The Irish government could credibly claim that its position was protective of existing all-Ireland integration and cooperation rather than any kind of irredentist claim. Nevertheless, when compared with the policy and discourse from 1998 until 2016 it was a major change. Relations with the DUP declined and this was probably inevitable once the negotiations started, also, given the intergovernment/supranational nature of the process the Irish government was bound to 'go over the heads of the Unionists'. The Irish government also explicitly reached out to the devolved governments in Scotland and Wales (who shared a desire for a 'soft Brexit'). The drama increased when the UK compromised on the financial settlement and on the rights of EU citizens in the UK, leaving Ireland as the major stumbling block to a deal. A new level of tension between the two governments had emerged (Tannam, 2019: 9) and in the media and social media familiar tropes of Anglo-Irish discord reasserted themselves. The EU member states and the EU institutions maintained strong support for the Irish position, forcing the British government to compromise further. In the final agreement the UK unilaterally agreed that if a border could not be avoided via the EU-UK trade agreement or specific ideas of its own 'the United Kingdom will maintain full alignment with those rules of the Internal Market and the Customs Union which, now or in the future, support North-South cooperation, the all-island economy and the protection of the 1998 Agreement' (European Commission, 2017). (The all-island economy mentioned is significant as this goes beyond trade in goods). In response to initial protests from the DUP a further article was inserted stipulating that the UK government would ensure that no new barriers emerged between $\mathrm{NI}$ and the rest of the UK. However, it was clear that the UK had accepted the principle of specific arrangements for Ireland. Subsequent EU interpretation of this 'backstop' was that discrete customs and regulatory arrangements would need to be in place for Northern Ireland should the EU and the UK be unable to agree frictionless trade more broadly. Although this distinctiveness for Northern Ireland was diluted in the withdrawal agreement agreed with the UK government in November 2018 it still applied. 


\title{
Box 2: Varadkar's speech at Queens University Belfast
}

\author{
'The Future of Relationships North and South' \\ After preliminary remarks the new Taoiseach discusses the island of Ireland's troubled \\ past. He pinpoints the border that existed before the 1990s as a symbol of division and a \\ barrier to trade and cooperation. He then deploys liberal discourse to describe the \\ modernisation of Ireland including legal changes and greater individual liberties. The \\ 'open' and multicultural nature of Ireland is stressed as is the GFA and the principle of \\ accepting 'difference' before returning to liberal discourse in emphasising the normality \\ of multiple identities.
}

He also draws on European integration discourse stressing the importance of European identity before going onto the seriousness of Brexit and its implications.

'I passionately believe that being European is an essential part of the modern Irish identity, an enhancement not a dilution of who we are....'

Brexit is presented as a threat to these achievements and to daily life. He asserts his own responsibility and authority in the 'historic' negotiation process.

'In October, I will sit around the European Council table with 26 other Prime Ministers and we will decide together whether sufficient progress has been made.'

Emphasising the legal dimension he stressed the Irish government's 'responsibilities as coguarantors of the Good Friday Agreement' and the need 'to protect our peace, our freedom, our rights, and our prosperity'.

Continuing the liberal discourse he emphasises his preference for a transnational solution

'I do not want there to be an economic border on our island nor do I want one between Ireland and Britain.'

The blame for this is placed squarely on 'the Brexiteers'

'there are people who do want a border, a trade border between the United Kingdom and the European Union and therefore a border between Ireland and Britain... I believe the onus should be on them to come up with proposals'.

The speech ends by returning to practical matters of North South cooperation (sport and transport).

Source, Varadkar, 2017a. 
Figure 2 Language and phraseology used to refer to the Irish border

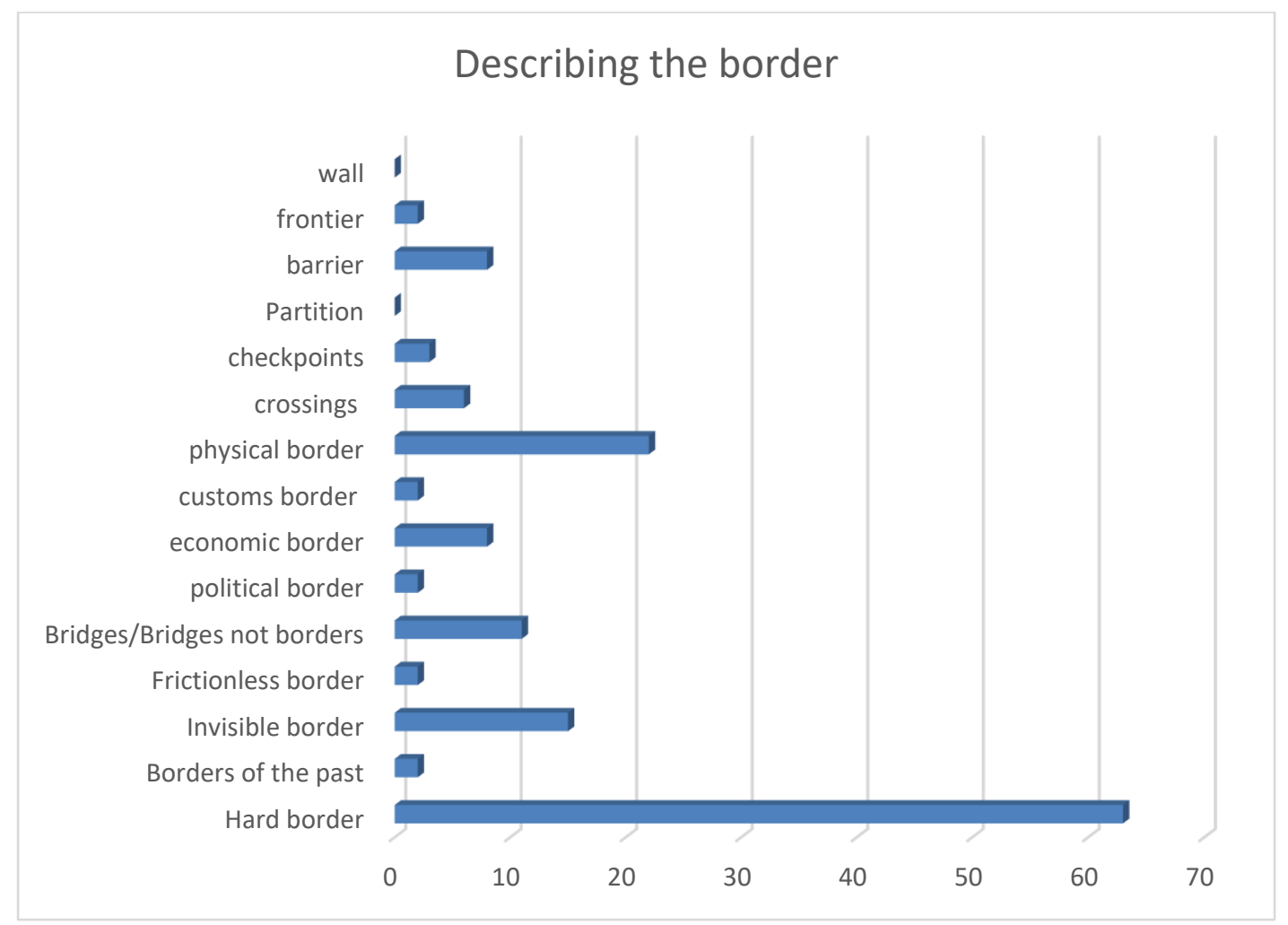

Figure 3 The spatial dimension of cooperation (references to East-West and North-South)

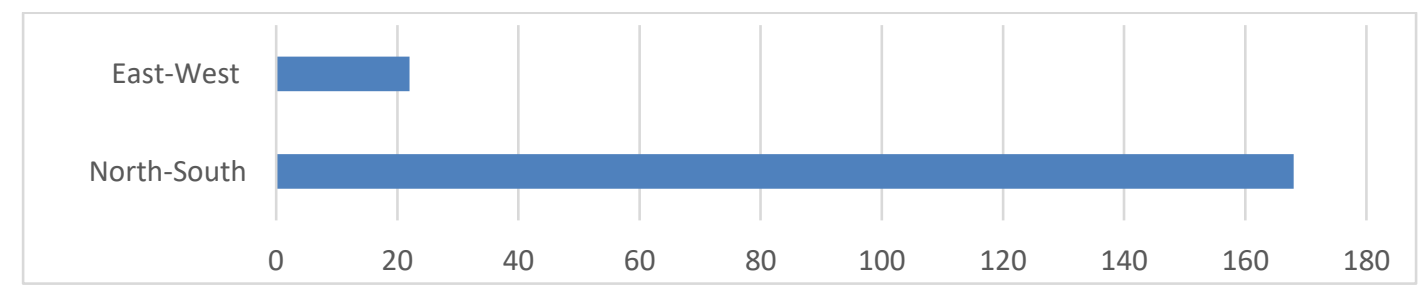


Figure 4 An elementary classification of the emotional language used to discuss Brexit
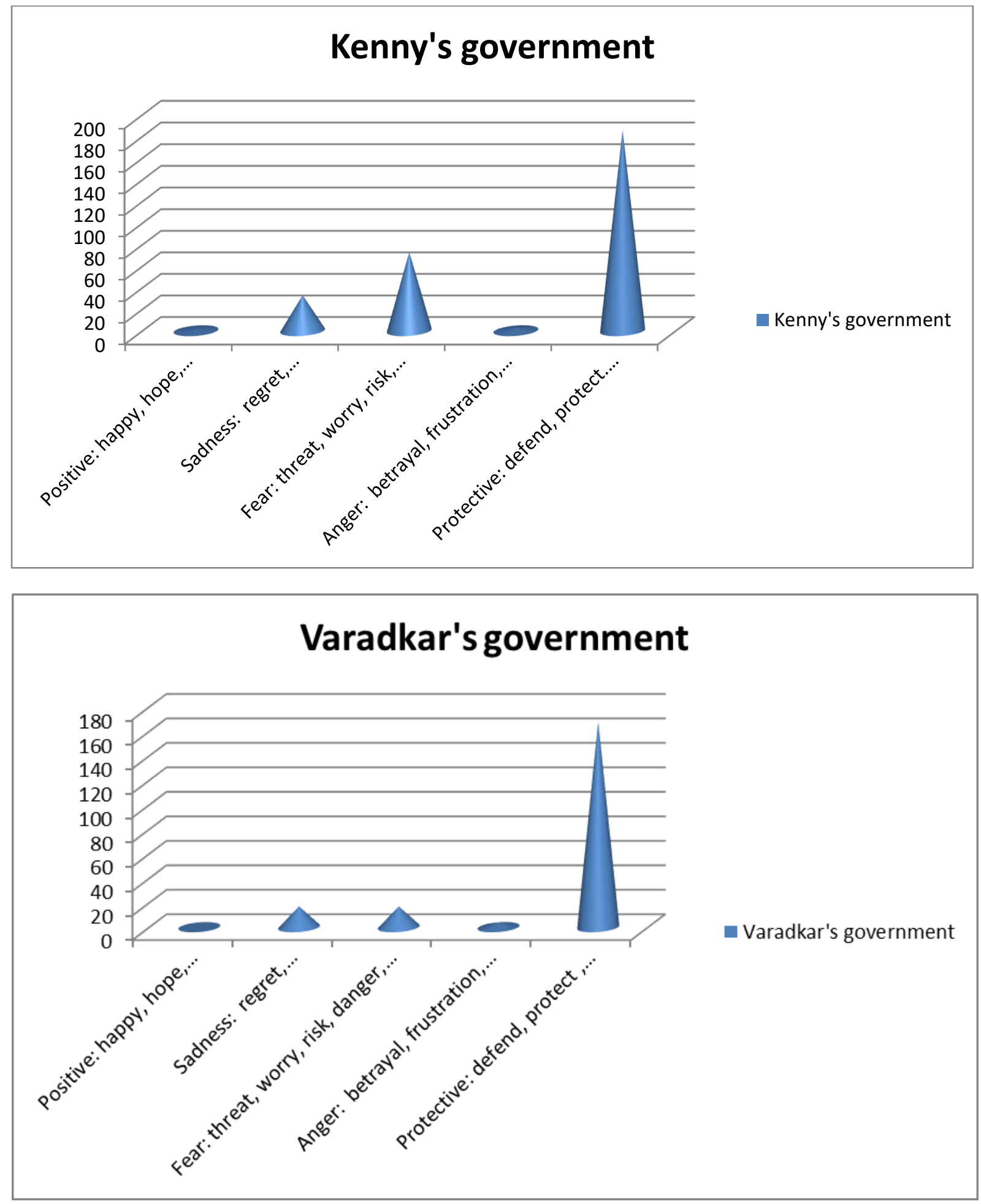
There has been much commentary on the more assertive approach of the new government. In fact Enda Kenny had also stressed a strong line on the border. As noted in the content analysis of the 75 texts (see figure 4), the Irish government's language throughout was focused on the need to protect the status quo and the Good Friday Agreement. (They also stress the need to protect European unity and cohesion ${ }^{1}$ ). Throughout this period the Irish government has not used highly emotional or recriminatory language (although under Varadkar it was more forthright). What was new from Varadkar's government was the direct framing of responsibility and the invocation of Irish power/influence vis a vis the EU's progress. Generally there is a strong emphasis on guarding the status quo on the island of Ireland rather than any sense of political unity. The term 'united Ireland' is cited 21 times (an increase compared to normal discourse) but this is usually to downplay the concept, the main focus is on cooperation/integration on 'the island of Ireland'. In discussing the border the government avoided the old politicised language of partition rather stressed that it was happy with a political border but that it should be invisible, not physical, relying on the image of a 'hard border' to emphasise this point (figure 2). Other geographical language reflects traditional Irish preoccupations in particular the North-South frame fostered by the GFA (figure 3) and the rejection of the term British Isles which is not used once (the alternative of 'these islands' is used). It is also noteworthy that relatively trivial or violent terms such as 'divorce' (two mentions) or 'cliffedge' (seven mentions) were rarely used by Irish representatives (in contrast with the British and EU counterparts).

\section{Discourses and power relations}

Ireland's discourse has generally reflected that of the EU more generally. The EU's response has been understandably defensive and been pervaded with realist - in international relations terms discourse, for example Donald Tusk's calls to 'defend the interests of the 27 ' (Tusk, 2017). The emphasis was to display unity and also assert its authority regarding the 'integrity' of the single market in particular the indivisibility of the four freedoms (European Council 2017). The single market is the basis of the EU's structural power and the article 50 helps actualise this as it creates a cliff edge scenario for the departing state. As the UK is the smaller entity, trying to break away the pressure is mostly on it to accommodate the wishes of the transnational capital and their representatives. Yet it cannot do this without agreement from the EU, which maintains (not illogically) that the UK's self-declared red lines prevent it from fully participating in the single market. The EU has been unyielding here and made no effort to construct a new legal-economic system that

\footnotetext{
${ }^{1}$ There was also a stress on protecting people's rights, free flows of people and Ireland's economic interests.
} 
would rebalance the rights and obligations of single market membership in a way that suits UK political needs. It adopted a standard hegemonic technocratic discourse (also used with accession countries or recalcitrant governments such as Syriza in Greece in 2015) in which the existing European political and regulatory space is framed as an immutable 'reality' with which the UK will have to accommodate itself. Political disagreements are framed as misunderstandings or worse on the partner's part. Is this case the UK government has been consistently framed (not without objective evidence) as unreliable , unrealistic, unprepared, lacking 'clarity', unsure of what it wants, harbouring 'illusions' and obsessed with irresponsibly and selfishly cherry-picking the benefits of European integration. EU leaders, such as chief negotiator Michel Barnier have been quick to correct and clarify the UK's positions and approaches and have given consistent signals to global market that the UK will be an inferior base within the Europe economic space in future. The UK government has tried to occlude the problem of the Irish border by stressing that the future arrangements can be frictionless via a free trade agreement. This is based on a hyper neoliberal discourse of global free trade expounded by a marginal group of experts in which barriers to free trade can be surmounted by relatively minimalist agreements (Siles-Brügge, 2018). Liam Fox's invocation of a post-geography trading world is emblematic of this discourse (Fox, 2016). To the contrary EU leaders have found themselves emphasising the geographical embeddedness and particularity of European economic integration, which employs extensive institutions and laws to enable 'frictionless trade'. Note Barnier's direct contradiction of the UK's hope for frictionless trade outside of the Single Market and Customs Union (2017). Irish discourse aligns with this in that the pre-existing EU legal framework is not considered up for debate (even if that might suit Ireland's own economic interests). Northern Ireland and the border problem represent the most concrete example of geographical realities that impinge upon the vision of global Britain. Visits to the border of European leaders became a kind of media ritual to illustrate the physical difficulties of re-imposing controls. The Irish framing of the border problem chimes with a broader EU approach in forcing the UK to confront trade-offs between its global desires and its needs/responsibilities in its neighbourhood.

The consistent features of the Irish discourse have been as follows. Ireland identifies with, and is firmly anchored, in the European Union. Its close relationship with the UK is acknowledged but definitively second place behind the EU 'family'. At the same time the Irish leadership portrays Irish vulnerability and potential as an innocent victim of Brexit. This is in contrast to the EU which paints Brexit as a relative sideshow which is damaging but essentially manageable (Elder and Herszhenhorn, 2017). Brexit has not been framed as a bilateral issue. Ireland's 'Europeanness' draws on a broader discourse of liberal internationalism to portray Ireland as - in the words of its 
Taoiseach - 'an Island at the centre of the world' (Time, 2017), building on the classic spatial metaphor of Ireland wanting to be 'at the heart of Europe' (while the UK is painted as a peripheral, marginal 'third country'). The new leadership team went further than the previous government in articulating the power that EU membership gives member states and the economic power of the EU more generally (together with the need to the defend the 'integrity' of the single market).

The issue of Northern Ireland is approached not in an expansive or nationalistic manner but a protective one. The government does not advance a maximalist interpretation of the Good Friday Agreement, which could be read to argue that Northern Ireland cannot be taken out of the EU against its will (O'Leary, 2016). However, the ideas supported by the Irish government were a significant departure from the peace process era. While there is some room for debate on the precise impact of customs and regulatory equivalence (the Irish government initially distinguished it from 'membership' of the customs union/single market per se) there is no doubt that this would make Northern Ireland a separate economic space from the UK (assuming it follows through on the Brexit vision). During this process there was some recourse to nationalistic (patriotic) discourse. Varadkar emphasised that the Irish national story was about taking a different path to the UK (Varadkar 2017b). In December 2017 he said to the nationalist people of Northern Ireland that they would 'never again be left behind by the Irish government' (Varadkar, 2017c). As such the dynamic of Brexit has stimulated a type of nationalism within Ireland. In fact there is a strong historical pedigree of combining nationalism with internationalism in Ireland and even the relatively insular Ireland of the 1930s strongly supported powerful international institutions which would constrain sovereignty (Gageby, 1999: 37). In this case the moderate nationalist discourse is subsumed within the dominant discourses of protecting transnational space and the rights of EU citizens. The 'four green fields' of historical Irish nationalist discourse (referring to the 4 provinces of the island) have been replaced by the 'four freedoms' of the European Union.

\section{Conclusion}

This paper has applied the case of Brexit to broader questions of geoeconomics and territorial politics. In particular it has investigated how political leaders framed this link in the crucial first stage of negotiations. This qualitative but systematic and in-depth analysis of Irish leaders' language on the issue gives a new level of insight into how irish politicians dealt with the threat of dis-integration. The UK's decision to leave the EU and its customs union and single market sparked a new form of power struggle between the UK and Ireland over the socio-economic regulation of Northern Ireland but not over sovereignty. The Irish state pursued a nuanced but determined campaign to use the 
power of the European Union to support its claims to protect the GFA and distinguish NI from the rest of the UK (if necessary). A predictable dynamic took place as the negotiations developed and the incompatibility of the various objectives (especially the UK leaving the customs union/single market and the desire to maintain an invisible border) became clear. As such the sharp contrast made between Varadkar's government and his predecessor is not valid. The former took a much sharper tone and was more explicit but the core Irish policy was consistent. Overall, the change in language since the Brexit vote was very striking. Core trade issues, particular in agriculture, emerged as the most salient issues in framing the problem of the UK's desire to separate itself from the European regulatory space but maintain frictionless trade. The distinction between a general political and economic border and a 'hard border' with physical infrastructure was core to the Irish argument. The reality of the physical geography of the border became an argument for the island of Ireland approach. The Irish government also succeeded in framing Brexit as a threat to peace and the Good Friday Agreement. The implications of this process for the island is that it shows how the GFA is understood to establish an island of Ireland economic space (thus constraining $\mathrm{NI}$ and the UK more broadly). The political agreement of December 2017 did not solve the challenges of Brexit for Ireland but it placed the principle of a 'backstop' for Northern Ireland squarely on the agenda.

Subsequently the UK's red lines regarding a customs union and following EU law were watered down but in this initial period they shaped the negotiation dynamic. They stimulated the EU to take a geoeconomically realist approach to future cooperation. This posed a threat to Ireland as it made a hard border with the EU more likely. It did not attempt to challenge the core consensus within the EU and rather tried to mobilise EU power for its ends, basing its framing on the immutability of the European legal framework. In another sense the UK's hardline position helped Ireland marshal European support to confront the UK with tough choices and to support its framing of the Northern Ireland 'problem'. Brexit is a new phenomenon of dis-integration in Europe, and it is clear that it can force the emergence of classic territorial disputes albeit in a new transnational context. The Irish government framed its approach not in terms of nationalism but in supporting peace and transnationalism/Europeanism. As such we have what appears to be the oxymoron of a nonnationalist territorial claim. The Irish government approach could be framed as the 'claiming of territory' (of a sort) but they would frame it as the protection of transnational space. The Irish government generally claimed to be representing the interests of the people of Northern Ireland as a whole rather than the nationalist community (although this latter element did appear). However, the political dynamic of the negotiation obscured these nuances and it took on the form of a classic orange-green dispute in several respects. From an international relations perspective, what is most 
striking is the fact that a small state was able to exert power over its much more powerful neighbour through its membership of the regional integration institution. However, one cannot extrapolate too much from this as to the power benefits of regional integration as this is a unique case; the UK was in the process of leaving (member states were bound to side with the remaining state) and the British government had badly misjudged its economic leverage. Thus it put the UK in a uniquely weak position. This study has been based on public texts and it could be supplemented by private discourse (interviewing) of elites on either side. Clearly there is room for more applied research on the practical degree of alignment needed to maintain all-Ireland integration in different sectors the context of Brexit. More broadly, given the trends in the global system there is a need to further study the impacts of economic dis-integration on spatial politics. While Ireland is clearly a unique case there are many other dormant territorial disputes in Europe that could be rekindled in the case of dis-integration (for example the South Tyrol). For the case at hand it is already clear that the prospect of Brexit transformed Irish-UK relations in discourse and practice in a short period of time.

\section{References/Bibliography}

Ahern, B. (1998) Statement to the Dail, Tuesday, 21 April 1998.

http://oireachtasdebates.oireachtas.ie/debates\%20authoring/debateswebpack.nsf/takes/dail19980 $\underline{42100008}$ (accessed 16 March 2017).

Anderson, J. (2017) Ireland's borders after Brexit, 28 July 2017 http://www.esrc.ac.uk/news-eventsand-publications/news/news-items/ireland-s-borders-after-brexit/ (accessed 16 March 2017).

Anderson, J. (2007) 'An Empire Once Again' in Geopolitics of European Union enlargement: the fortress empire, Armstrong, W. and Anderson, J. (eds) (London: Routledge).

Barnett, M. and Duvall, R. (2005), 'Power in International Politics', International Organization, 59: $39-75$.

Barnier, M (2017) Speech by Michel Barnier at the European Economic and Social Committee http://europa.eu/rapid/press-release SPEECH-17-1922 en.htm 
(accessed 16 March 2017).

Bertelsmann Stiftung, (2015) Brexit: potential economic consequences if the UK exits the EU (May 2015): https:// www.bertelsmann-

stiftung.de/fileadmin/files/BSt/Publikationen/GrauePublikationen/Policy-BriefBrexiten_NW_05_2015.pdf [accessed 16 July 2017]

Browning, C. (2018) 'Geostrategies, geopolitics and ontological security in the Eastern neighbourhood: The European Union and the 'new Cold War" Political Geography 62 (1): 106-115.

Bürkner, H-J. (2017) 'Imaginaries ready for use: Framings of the bordered intersectionalised everyday provided by the EU's sectoral policies' Political Geography Available online 16 June 2017 https://doi.org/10.1016/j.polgeo.2017.06.003

Coakley, J. and O'Dowd, L. (2007), ' The transformation of the Irish border', Political Geography 26: 877-885.

Coakley, J., Laffan, B. and J. Todd (eds), (2005), Renovation or Revolution: new territorial politics in Ireland and the United Kingdom, University College Dublin Press

Connelly, T. (2017) Brexit and Ireland: The Dangers, the Opportunities and the Inside Story of the Irish Response, Penguin: Milton Keynes.

Connelly, T. (2018) EU Ombudsman calls for publication of key Brexit report on Northern Ireland, RTE News Website, https://www.rte.ie/news/brexit/2018/1119/1011801-brexit-northern-ireland/ (accessed 19 November 2018)

Consilium (2016) Joint statement by the 27 heads of state or government on the outcome of the referendum in the UK, 29th 6th 2016 http://www.consilium.europa.eu/en/press/pressreleases/2016/06/29-joint-statement-informal-meeting-27/ (accessed 16 March 2017).

Coveney, S. (2017b) BBC Newsnight interview 16 August 2017, https://www.youtube.com/watch?v=g2HKFsmcLjs (accessed 16 March 2017).

Coveney, S. (2017a) RTE News at One interview 28 July 2017

CSO/Central Statistics Office, (2016) Brexit: Ireland and the UK in numbers, http://www.cso.ie/en/media/csoie/releasespublications/documents/statisticalpublications/Brexit.p df (accessed 16 March 2017).

CSO/Central Statistics Office (2003) 'Ireland and the EU 1973-2003 Economic and Social Change' https://www.cso.ie/en/media/csoie/releasespublications/documents/statisticalyearbook/2004/irela nd\&theeu.pdf (accessed 5 May, 2019)

Damro, C. (2012) 'Market Power Europe 'Journal of European Public Policy Volume 19 (5): 682-699

Department for Exiting the EU (2017a) Northern Ireland and Ireland: A Position Paper, https://www.gov.uk/government/publications/northern-ireland-and-ireland-a-position-paper (accessed 16 March 2017). 
Department for Exiting the EU (2017b) Future customs arrangements - a future partnership paper, https://www.gov.uk/government/publications/future-customs-arrangements-a-future-partnershippaper (accessed 16 March 2017).

Department for Exiting the EU (2018) Technical explanatory note on the North-South cooperation mapping exercise, 8 December 2018, https://www.gov.uk/government/publications/technicalexplanatory-note-north-south-cooperation-mapping-exercise (accessed 16 April 2019).

Diez, T., Albert, M. and Stetter, S. (2008) The European Union and Border Conflicts: The Power of Integration and Association, Cambridge: Cambridge University Press.

Doherty, B. McCrudden, C. , McGowan, L. Phinnemore, D. Schiek, D. and J. Temple (2017) Northern Ireland and Brexit: the European Economic Area option. EPC Discussion Paper, 7 April 2017.

Downing, J. (2017) Ireland and EU allies vow to fight for fishing industry as UK pulls the plug on agreement July 3rd 2017, http://www.independent.ie/business/brexit/ireland-and-eu-allies-vow-tofight-for-fishing-industry-as-uk-pulls-the-plug-on-agreement-35887780.html (accessed 16 March 2017).

Elder, F. and D. Herszhenhorn (2017) 'Brexit will never be a success', 5/3/17, http://www.politico.eu/article/brexit-will-never-be-a-success-junckers-top-aide/ (accessed 16 March 2017).

European Council (2107) Art. 50 guidelines for Brexit negotiations, http://www.consilium.europa.eu/en/press/press-releases/2017/04/29-euco-brexit-guidelines/ (accessed 16 March 2017).

European Commission (2017), Joint report from the negotiators of the European Union and the United Kingdom Government on progress during phase 1 of negotiations under Article 50 TEU on the United Kingdom's orderly withdrawal from the European Union.

https://ec.europa.eu/commission/sites/beta-political/files/joint report.pdf (accessed 16 March 2017).

Fairclough, N. (2010a) Critical discourse analysis, organisational discourse and organisational change, Pearson: Harlow, pp. 347-375.

Fairclough, N. (2010b) Global Capitalism Terrorism and War a discourse analytical perspective, Pearson: Harlow, pp. 478-503.

FitzGerald, G. (1991) All in a life : an autobiography, London : Macmillan

Fitzgerald, G. (2004) 'The Economics of EU Membership', in J. Hourihane ed., Ireland and the European Union: the first thirty years, Dublin: the Lilliput Press, pp. 67-81.

Flanagan, C. (2016a) Ministerial address at the Centre for Cross Border Studies Annual Conference 1 March 2017.

Finnemore, M. and K. Sikkink (2001) 'Taking Stock: The Constructivist Research Program in International Relations and Comparative Politics' Annual Review of Political Science, 4: 391-416. 
Fox, L. (2016) Speech delivered by International Trade Secretary Liam Fox at the Manchester Town Hall on 29 September 2016. https://www.gov.uk/government/speeches/liam-foxs-free-trade-speech (accessed 9 september 2018).

Gageby, D. (1999) The Last Secretary General: Sean Lester and the League of Nations, (Dublin: Town and Country House).

Government of Ireland (2017) Ireland and the negotiations on the UK's withdrawal from the European Union The Government's Approach, May 2017, https://merrionstreet.ie/en/EUUK/Key Irish Documents/Government Approach to Brexit Negotiations.pdf (accessed 16 March 2017).

Hayward, K (2018) The Brexit Border in 4 key slides, http://qpol.qub.ac.uk/brexit-border-4-keyslides/ (accessed 9 September 2018).

Hayward, K Campbell, M and R Murphy 2017 'The Irish Border as a Customs Frontier after Brexit', Tuesday, 11 July 2017 https://www.ceps.eu/publications/irish-border-customs-frontier-after-brexit (accessed 16 March 2017).

Holden, P. (2017) 'Neo-liberalism by default? A critical discourse analysis of the European Union's trade and development policy in an era of crisis', Journal of International Relations and Development, 20 (2) : 381-40.

HMRC (2017) UK Overseas Trade Statistics June 2017, https://www.gov.uk/government/uploads/system/uploads/attachment data/file/636178/OTS Rele ase 062017.pdf (accessed 16 March 2017).

Hourihane, J. (2004) 'The Dynamics of Membership' in J. Hourihane ed., Ireland and the European Union: the first thirty years, Dublin: the Lilliput Press, pp., 1-12.

House of Commons (2017) Brexit Negotiations: The Irish border question, Commons Briefing papers CBP-8042 Authors: John Curtis; Paul Bowers; Terry McGuinness; Dominic Webb, http://researchbriefings.parliament.uk/ResearchBriefing/Summary/CBP-8042 (accessed 16 March 2017).

House of Lords (2017) European Union Committee 6th Report of Session 2016-17 HL Paper 76 Brexit: UK-Irish relations, https://publications.parliament.uk/pa/ld201617/Idselect/ldeucom/76/76.pdf (accessed 16 March 2017).

Hume, J. (1994) 'A New Ireland in a New Europe' in Keogh and Haltzel eds., Northern Ireland The Politics of Reconciliation, Cambridge University Press.

Kaplan, D. and J. Häkli, (2002) Boundaries and Place: European Borderlands in Geographical Context, Lanham, MD: Rowman \& Littlefield, 2002.

Kenny, E. (2016a) Statement on the UK Vote to Leave the European Union - 24 June 2017.

Kenny, E. (2016b) Statement in the Dáil on the UK EU Referendum Result Monday 27 June 2016. 
Kenny, E. (2016c) Address to the British-Irish Association, Oxford, 9 September 2016.

Kenny, E. (2017) Address by the Taoiseach to the Institute of International and European Affairs, 15 February 2017.

Lakoff, G. (2001) 'Metaphorical Thought in Foreign Policy: Why Strategic Framing Matters', The Frameworks Institute, Online http://www.frameworksinstitute.org/assets/files/PDF Gll/metaphorical thought.pdf (accessed 16 March 2017).

Lord Kilclooney (2017) Irexit at same time as Brexit, Fri, Jul 29, 2016, https://www.irishtimes.com/opinion/letters/irexit-at-same-time-as-brexit-1.2737614 (accessed 29 August 2017).

Luttwak, E. (1990), 'From Geopolitics to Geoeconomics: Logic of Conflict, Grammar of Commerce'. The National Interest, 20: 17-23.

Mann, M. (1986) The Sources of Social Power: Volume I a history of power from the beginning to A.D. 1760, (Cambridge: Cambridge University Press, 1986), pp. 1-33.

Martin, M. (2016) Contribution to Dáil Éireann debate 27/Jun/2016 on the United Kingdom Referendum on European Union Membership. http://oireachtasdebates.oireachtas.ie (accessed 16 March 2017).

Martin, M. (2017) Contribution to Dáil Éireann debate - 04/Apr/2017 Brexit: Statements. http://oireachtasdebates.oireachtas.ie (accessed 16 March 2017).

McAdam, N (2017) 'DUP bristles over Dublin threat to wield Brexit veto', http://www.belfasttelegraph.co.uk/news/brexit/dup-bristles-over-dublin-threat-to-wield-brexitveto-36059542.html (accessed 16 March 2017).

Minihan, M. (20170 Defiant Varadkar tells British: we won't design Brexit border for you, Irish Times, 28 July, https://www.irishtimes.com/news/politics/defiant-varadkar-tells-british-we-won-t-designbrexit-border-for-you-1.3170014 (accessed 16 March 2017).

Mulhall, (2017) Address to the European-Atlantic Group, http://www.theirishworld.com/danmulhall-brexit-british-irish-relations/ (accessed 16 March 2017).

North-South Ministerial meeting (2017), 23rd Plenary Council communique, https://www.northsouthministerialcouncil.org/sites/northsouthministerialcouncil.org/files/publicati ons/Paper\%20NSMC\%20P2\%20\%2816\%29\%20JC\%20-\%20Joint\%20Communiqu\%C3\%A9\%2018\%20 Nov\%202016 0.pdf (accessed 16 March 2017).

Ohmae, K. (1995) The End of the Nation - State: The Rise of Regional Economies, New York: The Free Press.

O'Callaghan, C. and M. Gilmartin, (2016) 'Ireland: borders and borderlines' Soundings: A journal of politics and culture Issue 64, Winter 2016-7 pp. 64-70 
O'Dowd, L. (2007) 'The three ages of the Irish border' in Geopolitics of European Union enlargement: the fortress empire, Armstrong, W. and Anderson, J. (eds) (London: Routledge).

O'Duffy B. (2000) 'British and Irish Conflict Regulation from Sunningdale to Belfast. Part II: Playing for a draw 1985-1999', Nations and Nationalism, 6 (3), pp. 399-435.

O'Leary, B (2016) The Dalriada Document: Towards a Multi-National Compromise that Respects Diversity in the United Kingdom,

http://www.centreonconstitutionalchange.ac.uk/sites/default/files/papers/The\%20Dalriada\%20Doc ument.pdf (accessed 16 March 2017).

Popescu, G. (2008) 'The conflicting logics of cross-border reterritorialization: Geopolitics of Euroregions in Eastern Europe' Political Geography 27 (4): 418-438.

Rosamond, B. \& Hay, C. (2002) Globalization, European integration and the discursive construction of economic imperatives, Journal of European Public Policy, 9 (2), pp. 147-167.

Roper, S. (2007) Cross-border and local co-operation on the island of Ireland: An economic perspective, Political Geography 26 554-574.

Siles-Brügge, B. (2018) 'Bound by Gravity or Living in a 'Post Geography Trading World'?' New Political Economy, https://doi.org/10.1080/13563467.2018.1484722

Sinn Féin (2017) Brexit risks destroying the Good Friday Agreement - Adams, ttp://www.sinnfein.ie/contents/43147

Stokłosa, K. and G. Besier (eds.) (2014) European Border Regions in Comparison: Overcoming Nationalistic Aspects or Re-Nationalization? (London: Routledge)

Strange, S. (1988), States and Markets, London: Pinter.

Tannam, E. (2019) 'The Future of the UK-Irish Relations' DCU Working Paper N. 3-2019, https://papers.ssrn.com/sol3/papers.cfm?abstract_id=3357165 (accessed 17 May 2019).

Thomas, R. and P. Turnbull (2017), 'Talking up a storm? Using language to activate adherents and demobilize detractors of European Commission policy frames' Journal of European Public Policy 24 (7): 931-950.

The Downing Street Declaration (1993) Cain Web Service

http://cain.ulst.ac.uk/events/peace/docs/dsd151293.htm (accessed 16 March 2017).

The Good Friday Agreement (1998) https://www.gov.uk/government/publications/the-belfastagreement (accessed 16 March 2017).

TIME Magazine (2017) Interview with Leo Varadkar on EU, Brexit, Trump, 13 July 2017.

Tusk, D (2016) Speech by President Donald Tusk at the European Policy Centre conference 2 October 2016 http://www.consilium.europa.eu/en/press/press-releases/2016/10/13-tusk-speech-epc/ (accessed 16 March 2017). 
Varadkar, L (2017a) Speech by the Taoiseach Mr. Leo Varadkar TD, Queen's University, Friday 4 August 2017 - 'The Future of Relationships North and South' - Department of Taoiseach

Varadkar, L (2017b) Speech by An Taoiseach, Leo Varadkar, Leader of Fine Gael (speech to Fine Gael ard fheis) 10 November 2017 https://www.finegael.ie/speech-taoiseach-leo-varadkar-leader-finegael/ (accessed 16 March 2017).

Varadkar, L (2017c) Statement by the Taoiseach Leo Varadkar T.D. Friday 08 December 2017, Government Press Centre.

https://www.taoiseach.gov.ie/eng/News/Taoiseach's Press Releases/Statement by the Taoiseach Leo Varadkar T D Friday 08 December 2017 Government Press Centre .html (accessed 16 March 2017).

Vihma, O. (2017) 'Geoeconomic Analysis and the Limits of Critical Geopolitics: A New Engagement with Edward Luttwak', Geopolitics, Published online: 05 Apr 2017, https://doiorg.plymouth.idm.oclc.org/10.1080/14650045.2017.1302928, (accessed 16 March 2017).

Warren, T, Holden, P. and K. Howell (2017) 'The European Commission and fiscal governance reform: a strategic actor?' West European Politics, 40 (6) 1310-1330.

Whelan, N. (2017), 'Not insisting on place at Brexit table may prove costly', https://www.irishtimes.com/opinion/noel-whelan-not-insisting-on-place-at-brexit-table-may-provecostly-1.3189796 (accessed 16 March 2017).

White, T. (2017) Theories of International Relations and Northern Ireland, Manchester, U.K. : Manchester University Press.

Wilkinson, R. (2006), The WTO, crisis and the governance of international trade, London: Routledge. 